\title{
Collaboration and Its Distortion in Managing Migas' CSR Programs: A Case Study on the CSEL's Community Empowerment Program in the Salas Village, Bula Sub-District, Eastern Part Seram Regency, Maluku Province, Indonesia
}

\author{
Josep Antonius Ufi ${ }^{1}$, Zainal Abidin Rengifurwarin ${ }^{2}$, Jusuf Madubun ${ }^{3}$ \\ ${ }^{1,2,3}$ Faculty of Social \& Political Sciences, Pattimura University, Indonesia \\ Email: josepantoniusufi977@gmail.com
}

\begin{abstract}
This study aims to analyse the collaboration form of, and critically discuss the determinant factors of collaboration those are more significantly distorted, in the governance of CSEL's CSR program on agriculture-based economic empowerment for communities in the Salas village of Bula Sub-District, Eastern Part of Seram Regency in Maluku Indonesia. The collaboration form, the determinant factors of collaboration and their distortion as the main focuses were employed in a qualitative case study. Primary data was collected by using an in-depth interview and Focus Group Discussion. There are 9 key informants. Secondary data was collected by using documentary study on relevant documents (CSR rule \& regulation, CSR Reports, etc.). The CSEL's collaborative CSR program was a type of formal collaboration that was significantly distorted. The stakeholder, communication and also collaboration resources were among the determinant factors which were significantly distorted in the governance of the CSEL's collaborative CSR program, and therefore it failed for empowering the economy of the host community in the Salas Village. The findings of this study are useful to understand the specific formal collaborative management of CSR in Indonesian oil and gas sectors which were distorted in the CSEL's collaborative CSR program case; particularly, these findings show the challenges the oil \& gas sectors face in managing their collaborative CSR programs by improving the determinant factors of collaboration. This study adapts not only the concept of collaboration form, but also the well-known determinant factors of collaboration into a unique and specific case of CSEL's formalized collaborative CSR program within the Indonesian oil \& gas sectors context that was significantly distorted in practice if compared to other CSR programs of CSEL and others.
\end{abstract}

Keywords: The Determinants of Collaboration, Community Empowerment, CSR Program, CSEL.

\section{A. INTRODUCTION}

The collaborative approach in the context of public administration and governance today has been applied as an institutional mechanism that is considered more appropriate and efficient in managing developmental programs, while at the same time bridging the limitations between the public and private sectors, volunteer and communities (Sullivan \& Skelcher, 2002; Marek et al., 2014), so as it can fulfil various public objectives (Agranoff \& Guire, 1998), with no exception in managing 
various Corporate Social Responsibility (CSR) programs (Peloza \& Falkenberg, 2009).

While there are various reasons for the need for a collaborative approach in implementing developmental programs generally (Brinkerhoff \& Brinkerhoff: 2011; Dwiyanto, 2011), but as indicated, among others, by Marek at al,that little is known concerning practices that lead to successful collaboration; furthermore, by referring to Provan \& Milward (2001), and also to Sandoval et al (2011), Marek et al. then concluded that it was still too early to conclude the effectiveness of collaboration, despite its promise (Marek et al., 2014). Accordingly, there are also a variety of factors determine the success or failure of a collaboration (Mattessich et al., 2001; Cheever, 2006), including the CSR collaboration. It means that if there is a distortion on such determinant factors it can result in stalled and failure of the CSR program itself and tends to create community dependency (Jenkins \& Obara, 2008).

One of the empowerment oriented CSR programs that was implemented collaboratively by Citic Seram Energy Limited (CSEL), as the Non-Bula Block operator of the upstream of oil and gas sector (abbreviated: Migas sector) in Indonesian context, in particular in Maluku Province, was the CSEL's collaborative CSR program of socio-economic empowerment for disadvantaged community in the Salas Village, Bula Sub-District in 2013-2015, which also revealed, in certain ways, the phenomenon of the problems within the collaborative CSR programs that turn out to be less than optimal, distorted, even failing and tend to create dependency patterns from the community (Jenkins \& Obara, 2008; Ufi, 2018); besides the relatively optimal and successful ones (Ufi, 2018; Ufi et al., 2020). Furthermore, those phenomena indicate that there are at least two categories of the discontinuation problems in implementing the CSEL's CSR programs, that is, on the one side, the discontinuation that is influenced by lack or limitation of the recourses or structural problems; on the other side, the discontinuation problem that is influenced or caused by a distortive action the resources by the powerful with self -interest, in terms of, for example, misusing of the contract by the program manager (MPM), etc. (Yandra, et al., 2020).

This study try to focus on the distortive problem within the collaborative CSR program. Based on the background of the problem as described above, the author is encouraged to investigate further in order to explore the meaning behind the social phenomenon of the CSEL's collaborative CSR program, in particular, the collaboration determinants and its distortion within the program management by formulating the research questions, as follows: (1) What form of collaboration is applied in managing CSEL's CSR community empowerment program in the Salas Village community? (2) How far are the determinants of collaboration distorted in the CSEL's CSR community empowerment program in the Salas Village?.

This study aims to analyse the collaboration form of, and critically discuss the determinant factors of collaboration those are more significantly distorted, in the governance of CSEL's CSR program on agriculture-based economic empowerment for communities in the Salas village of Bula. The result of this study shows that the 
CSEL's collaborative CSR program was a type of formal collaboration that was significantly distorted. The stakeholder, communication and also collaboration resources were among the determinant factors which were significantly distorted in the governance of the CSEL's collaborative CSR program, and therefore it failed for empowering the economy of the host community in the Salas Village. The findings of this study are useful to understand the specific formal collaborative management of CSR in Indonesian oil and gas sectors which were distorted in the CSEL's collaborative CSR program case; particularly, these findings show the challenges the oil \& gas sectors face in managing their collaborative CSR programs by improving the determinant factors of collaboration. This study also has certain significant, while it is one of the formally collaborative CSR programs agreement of CSEL (K3S Migas) as regulated by the Law (Frynas, 2005; Edi, 2014), in fact, it was distorted significantly if compared to the informal ones (Ufi, 2018; Edi, 2014); besides, there is any different characteristic of the host community (Salas Villagers) in response to the program actualization compared to other collaborative CSR programs although still within the villages area of Bula-Subdistrict and others (Ufi, 2018; Fisip Unpatti, 2017; Nasdian, 2015).

\section{B. LITERATURE REVIEW}

\section{Conceptualizing Collaboration and Its Forms}

Based on his research on collaboration, Gray (1989) quoted by Guffey (2006) then defines collaboration as 'a process in which participants involved in the problem actively seek a solution that is set together'. Meanwhile, Sink (1998), referred by Dwiyanto (2010), defines collaboration as 'a process in which organizations that have an interest in a particular problem try to find solutions together to achieve goals that may not be achieved by themselves'. Himmelman (1996), defines that collaboration is considered as an empowering action. Chrislip \& Larson (1994), also stated that collaboration could lead to empowerment. It can be summarized that collaboration implies 'as a form of integrated collective cooperation based on a mutually beneficial relationship, the existence of shared goals, participants are relatively autonomous, interact with each other through formal and informal negotiations with mutually agreed arrangements, mutual trust, shared responsibility, as well as the benefits and risks together'. The main elements that characterize a collaboration include: (1) the element of collective collaboration with more than one agency; (2) there is mutual concern on shared problems; (3) there are shared goals; (4) joint decision making; (6) sharing roles and responsibilities according to available resources; (7) there are agreed collective actions; (8) there is an intensive relationship (formal \& informal); (9) there is trust in each other; and (10) sharing the benefits and risks together (Ufi, 2018).

There are various forms of collaborative management starting from an informal information exchange to a formal contract of collaboration (Sabaruddin, 2015). Informal dimension of collaboration, in general, refer to several aspects including mutuality and capital social such as the relation among actors, trust and 
reciprocity norm; while formal dimension of collaboration generally refers to various aspects including structural or governance and administrative aspects of collaboration (Thomson et al., 2007; Grudinschi et al., 2013; Ufi, 2018).

\section{Corporate Social Responsibility}

There are various definitions of corporate social responsibility (CSR), and its meanings vary across time and geographical space (Scherer \& Palazzo, 2010; Ufi, 2018). Lantos (2001)as quoted by Jamali et al., (2008), distinguishes between ethical CSR (moral mandates, transcending economic CSR and legal obligations of ethical responsibility); Altruistic CSR (humanistic CSR: improvement of quality of life, alleviation of ignorance and poverty); and strategic CSR as a strategic philanthropy with an orientation towards achieving strategic business goals while also promoting social welfare. The conceptual scope of CSR is broad, covering charity, empowering human abilities, involvement of stakeholders with their rights and obligations, collaboration and partnerships patterns, and addressing basic values. The concept of CSR is closely related to good (corporate) governance in order to embody the goal of sustainability, integrating social responsibility through community development, sustainable environmental development and human rights (Jamali, et al., 2008).

While other research focuses more on the informally collaborative CSR programs (Ufi, 2018; Ufi, et al., 2020), this research focuses more on such a formal one, and it is also in line with Peloza \& Falkenberg (2009) that focuses on CSR programs that involve collaboration with NGOs; It means that corporate CSR closely relates to community development, besides to the issues of corporate governance and environmental issues (Nasdian, 2015). On the one hand, CSR program governance in the perspective of community empowerment is actually centred on community participation, initiatives and processes from the community, guided in local ways and using facilities and mechanisms that can be controlled effectively. Meaningful participation of citizens in CSR activities initiated by the corporation, as well as a process of strengthening the capacity of the community to exit the problems faced from aspects of empowerment and the environment (Nasdian, 2015; Ufi, 2018), so that its implementation can answer the needs of the community and ensure the sustainability of its programs (Nasdian, 2015); CSR programs are truly a process oriented to grassroots communities (Andrews, 2013; Ufi et al., 2020), and their implementation through collaborative patterns, for example, is expected to be based on basic values, such as, equity, social inclusion, and empowerment (Brinkerhoff \& Brinkerhoff, 2011), rather than creating community dependency (Jenkins \& Obara, 2008). However, on the other hand, actualization of the CSR and community development, in fact, creates many false, dependency and scepticism of the community stakeholder (Frynas, 2005; Idemudia \& Ife, 2006; Eweje, 2007).

\section{CSR Governance and Its Collaboration in the National Oil and Gas Sector}


The governance of oil and gas CSR programs in Indonesian context is regulated in various specific regulations and policies, namely: Government Regulation (Peraturan Pemerintah, No. 35/2004), concerning Upstream Oil and Gas Business Activities: which includes in articles 72 and 73 concerning the obligation to implement environmental management and community development, article 74 concerning company responsibilities for local community development, by involving, developing and utilizing the potential capabilities of local communities, in order to create harmony between the company and the local community; and (3) its implementation in the Work Procedure Guidelines (PTK) 017/III/2005 of BP Migas, specifically contained in book II on Community Development, which include programs in the fields of economics, education and culture, health, social facilities and public facilities, and fields the environment, and its management pattern independently through the existing organizational functions, also the need to collaborate with stakeholders, both local governments, and universities, Nongovernmental organizations, private but also local communities.

The importance of structuring specifically for the CSR governance of the oil and gas sector is due to the fact that the oil and gas sector is a national vital object $(\mathrm{OVN})$ with special characteristics, including related to the direct and massive impacts of the changes resulting in the natural and social environment around the area of its operations, so special social and environmental responsibilities are also required from the K3S operator, as stipulated in the various rules and policies mentioned above. The involvement of local communities in the oil and gas CSR program is important because the local community is one of the company's key stakeholders (Pesmatzoglou et al., 2012; Jenkins \& Obara, 2008).

\section{The Determinants of Collaboration \& Its Distortion}

What is meant by the determinants of collaboration are various factors that positively determine (or negatively inhibit) the process and success of collaboration, including collaborative management of oil and gas CSR programs. This research based on the determinant factors of collaboration introduced by Mattessich et al. (2001);Cheever 2006) refers to Mattessich et al. (2001) by suggesting a variety of determinants of the success or failure of collaboration, those are: (1) environmental factor: which include the history of collaboration in the community, the legitimacy of leadership, and its social and political climate; (b) stakeholder factor in collaboration and their characteristics: which include respect and mutual trust between them, have the ability to interact across social boundaries and can compromise; (3) process and structure factors: which include sharing roles and responsibilities in the collaboration process and enjoying the results, there is a double layer of participation, flexibility, clear roles, work guidelines; have the ability to adapt (adaptability), and determine the appropriate development steps; (4) communication factors which include openness, frequency of formal and informal relations, and the ability to establish communication; and (5) collaborative goal and resource factors: which include concrete and attainable goals and objectives, shared vision, and clear 
goals; have sufficient funding, staff, material, time and leadership skills (Cheever, 2006; Smith, 2009).

Consequently, if there is distortion in various determinants of collaboration, it will bring stagnation, false developmental promises, and even scepticism and dependency(Cheever, 2006; Jenkins \& Obara, 2008; Kozuch \& SienkiewiczMalyjurek, 2016; Frynas, 2005; Huxham \& Vangen, 2005; Naf'iah, 2020; Ufi, 2018). The distortion means here the action of giving a misleading account or distorting by misusing or exploiting power and/or authority one has to the certain resources, for instance, in order to fulfil the self- interest, but under sacrificing the others' interest and to create culture of depencency (Idemudia \& Ife, 2006; Frynas, 2005) by misusing, for example, the contract by the powerful (Yandra et al., 2020). As it is the premise of resource-dependency theory, for instance, that one party attempts to use his/ her power to control or influence the other's activities, and such distortive condition as complaints relate to slow progress towards goals, lack of inclusiveness and domination by any partners (Smith, 2008; Sullivan \& Skelcher, 2002). It is different from the certain barriers or limitation of certain issues to the collaboration such as lack of organizational and technical capacities, and also un-sufficient supply of resources (Sabaruddin, 2015).

\section{METHOD}

This study is a type of qualitative research by using a case study approach. This qualitative research located in the Salas Village of Bula Sub-District and Citic Seram Energy Limited (CSEL) Office in East Seram Regency, Maluku Province. The key informants in this study were determined purposively by 9 persons, namely: Administrative Superintendent CSEL 2 persons, CSEL Public Relations Coordinator 2 persons, Head of CSR Program Manager from the Maluku's Muhammadiyah Community Empowerment Council (MPM) 1 person, Field Assistant 2 person, Salas Community Member 2 persons.

Field data collection was conducted in May 2016 to March 2017. Primary data were collected using (1) in-depth interview techniques to explore information, experience, knowledge and understanding of key informants and interview transcripts were made; and (2) field observations to observe the condition of objects in the field directly; Meanwhile, secondary data was obtained through the study of relevant documents including: proposed CSR program documents and reports on the implementation of CSR program activities, cooperation documents, brochures, and various regulations relating to the focus of research problems. The data collected was then analysed using descriptive qualitative analysis techniques which included, first: data reduction activities, second: data presentation, third: conclusion drawing/verification (Miles, Huberman, \& Saldana, 2014; Sugiyono, 2007).

\section{RESUL AND DISCUSSION}




\section{The form of Collective Cooperation in The Implementation of CSEL CSR Programs}

Data on the elements of collaborative collaboration in CSR programs in Salas village, Bula Sub-District, East Seram Regency were compiled from interviews with key informants and the results of document studies. As part of the Oil and Gas sector CSR program, the CSEL CSR program community economic empowerment collaboration in the village of Salas also refers to BP Migas PTK No. 017, 2005. Presented A.R. \& A.T., Admin Superintendent CSEL (June, 2016) and I.M. as Chairperson of the Maluku's Muhammadiyah Empowerment Council (MPM) who is also the manager of the CSR program (May, 2016), that the CSR program for community-based agricultural economic empowerment in Salas village is a collaborative program between CSEL and Maluku MPM, which was designed for three years (2013 to 2016). AI, as the Field Assistant (February, 2017) also acknowledged that the CSR program at Salas was a 'collaborative collaboration program between Citic (CSEL) and Muhamadiyah' (CSEL, 2015b; MPM, 2015).

CSEL is one of the K3S oil and gas development that operates in Non-Bula Block, East Seram Regency since 2006, after Citic Resources acquired 51\% shares of the Non-Bula Block from Kufpec (CSEL, 2015a). While the MPM partner is one of the completeness tools of the Muhammadiyah Organization of the Maluku Province (MPM, 2013).

It is certain confused because generally, a collaboration between or among private sector entity and non-governmental organization (NGO) entity is very recommended as a mode of social partnerships that can solve social and economic problems of the community through any collaborative community development programs (Parker, 2012; Seitanidi \& Crane, 2009), as showed, among others, by Andrews (2013) in his study on the collaborative CSR program in Ghana, and in Nigeria by Idemudia \& Ite (2006). However, the collaborative CSR program among CSEL (Oil \& Gas Company), MPM (a local NGO) and also the Salas community actually showed a different performance and result. Although it was designed for three years, the collaborative program had stalled at the beginning of the second year (2014), and of course it could not be continued, due to some of distortions (not just the condition of the resources limitation) in various determinants of collaboration. The distortion of the CSR program collaboration is evident from the absence of MPM's institutional collective and solid team work, but it is dominated by MPM program manager actors. Acknowledged by A.T. as Admin Superintendent and H.K., CSEL Public Relations Coordinator (June, 2016; October 2016), "as we know, MPM is I. M., nothing else"; A. I. as Field Assistant (February 2017) also admitted, "... we were only communicating with I.M. in MPM, there was no one else". In fact, I. M. on behalf of MPM monopolizes all decision roles with CSEL (signing the Cooperation Agreement, also the Person in Charge/Manager of CSR programs), without other MPM personnel. So, it is clear that there is a lack of collective and role positions of each stakeholder in the CSR program. This fact, at certain point, could reflect a mode of internal competition within the MPM organization, and within the CSEL field 
Management, but also, reflect external competition with other partners even with the local community in order to monopolize and exploit the collaborative resources that could also create a type of managerial dilemma (Naidoo, 2013).

\section{The Collaboration Determinants and Its Distortion in the CSEL CSR Program}

The determinants factors of collaboration here indicate the factors that determine the success or failure of the implementation and achievement of the CSR CSEL collaboration program objectives. The breakdown of CSEL's CSR program reflects distortions in various determinants of collaboration, this can be seen from the results of interviews with informants that are limited here to the factual determinant factors that dominantly distorted, namely: stakeholder, communication, and collaboration resources.

\section{Stakeholder}

Stakeholder factor includes: the skills, attitudes and opinions of the parties in collaboration, as well as the culture and organizational capacity that shapes collaboration (mutual respect and trust), being able to interact across social boundaries and being able to compromise, various participation, flexibility and adaptability (Mattessich et al., 2001). From the data collected, it is known that there are three main stakeholders involved in the CSR community empowerment collaboration program in the Salas village, namely: CSEL as the owner and user of the CSR program, the Society Empowerment Council (MPM), and the targeted program community in Salas Village, responsible for the CSR program is IM from MPM, and it turns out that the collaboration of the CSR program, which was designed for three years (2013-2016), was stalled in its implementation and no longer continued in the second half of 2014/2015 (CSEL, 2015b; MPM, 2015). Acknowledged by AT (October 2016 and HK (February 2017), that "in general there are three parties who have a significant role on the delay in the CSR program, the I.M., community, and also Citic ", but when explored further, in fact the dominance of distortion from the CSR program manager (I.M.). B.T. as the CSEL PR Coordinator, acknowledged that: "the most dominant person in controlling this program is only two people namely I.M. as the person in charge of MPM, and A.R. as the Superintendent Admin of CSEL ". A.I. (February 2017) as a companion of MPM also argued: '... so MPM that we see is only I. M., from CSEL the most frequently appear person in the field is A. R.". Furthermore, A.I. said that community factors also become obstacles. Villagers are not accustomed to group work and lack of participation, for example, when chickens are distributed, they are less likely to care for them.

Different things were said by the targeted villagers in Salas, according to A.M. (March 2017), "the companion style did not invite us to work, the people want to plant but they want to plant the seeds themselves"; Meanwhile according to G. T. (March 2017), "MPM (I. M.) only had a one-time socialization meeting with the villagers at the first time, and after that there was no follow-up meetings with villagers regarding the existing problems 
never occurred; procurement of seeds whether it is agriculture or livestock is not enough for the of scale villagers economies ...' (G. T., March 2017). A. I. also admitted (October 2016), "he (I. M.) rarely appears in the field, whereas we expected him to be present so that he would see it directly so that it would help to solve it". As a result, the local potential of citizens in terms of agriculture such as G. T. was not accommodated in the field.

From the data it is clear that weak managerial skills in I. M. as well as field facilitators, also the weak capacity of interaction across social boundaries, especially with residents, and tend to be not adaptive to the needs of citizens. For example, the provision of plant and livestock seedlings that are not in line with community expectations (not enough), goat seedlings that are held are generally female even though male goat are also needed, and the numbers are limited without clear standards. It can be assumed crucially not only about the technical capacity of, but also the legitimacy of, the manager as the main program stakeholder, as it is related to different views and interests among partners (Jamal \& Getz, 1995).

Likewise, the lack of coordination of the empowerment program with the regional government (Head of Sub-Districts \& related technical services) as one of the main stakeholders of oil and gas CSR which is also to support regional development programs in accordance with the mandate of PTK. BP Migas No.017 of 2005. Besides, as talked by local people that they were not included in the decision making and action, while they were only invited to give legitimacy of the program at initial stage, that is named by Ife \& Tesoriero (2014) just as a mode of tokenism. It was influenced by the power relationships that based on differential assumptions of status, authority, expertise and legitimacy among stakeholders within the collaborative initiative (Smith, 2008; Himmelman, 1996; Sullivan \& Skelcher, 2002). Accordingly, questions of such power relations, for example, and related issues are very important to understand the involvement of citizens and communities in any collaborative action with the powerful (Himmelman, 1996; Smith \& Beazley, 2002). While involvement of local communities in the oil and gas CSR program in particular is important because the local community is one of the company's key stakeholders (Pesmatzoglou, et al., 2012; Jenkins \& Obara, 2008), and even the empowering collaboration has to be based on the community (Vangen \& Huxham, 2003). In principle, the participation and involvement of local community as equal partners is also significant in order to fulfil the accountability of collaborative arrangements and the need to secure good governance (Sullivan \& Skelcher, 2002).

\section{Collaborative Resources}

Collaborative resources include, sufficient funding, staff, material, time and leadership skills (Cheever, 2006). Regarding program funds, it is known that the source of funds came from the 2013 Citic Operational Support Program (PPO) fund of Rp. 195 million and in 2014 Rp. 250 million, paid 100\% upfront to MPM (I. M.), while in 2015 the program did not continue (Cooperation Contracts and Program Reports 2014 \& 2015, CSEL, 2015b). CSR budget that is fully managed by I.M. it is actually sufficient for spending on programs and empowerment activities. However, 
various complaints from villagers regarding the lack of material and plant seeds needed, in certain ways, indicate a problem in the management of these funds, including, for example, lack of transparency and supervision from CSEL.

Related to the Human Resources (HR) program, it seems unclear the position and role of I. M. which is one side as the Head of MPM, but at the same time as the Person in Charge and Manager of the CSR program; and the presence of I.M. plays the role as MPM Leader in observing the field, but his role as manager and person in charge of the CSR program is less clear in the field. Furthermore, according to the Scope of Work (SoW) provision, the manager should provide a minimum of 4 field assistants every day who master the technical and administrative as well as managerial aspects of the agriculture and livestock program (CSEL, 2015b), but the fact is only prepared by 2 field assistants with minimal managerial and technical skills, especially in the field of livestock, as well as a lack of interaction skills across social boundaries (collaborative), which causes that technical personnel tend to do things themselves (land management, planting, cage making, etc.) without significant villagers participation. A.I. tends to assume that community members are lazy and do not want to participate, but villagers of Salas (A. M. \& G. T., March 2017) state that the facilitators do not communicate and invite villagers to work together, "... we are not lazy, but they (the facilitators) do not communicate; if they communicate with the community, the community will help ... ". The above data informs how the program manager (I. M.) has misused the contract (Yandra et al., 2020). In addition, it seems that program managers have not identified and accommodated the potential of local human resources, for example, G. T. He himself acknowledged having the skills and experience in farming and assisting, motivating and working with Salas villagers in agriculture, but this was not identified and accommodated by the Program Manager. Besides that, G. T. and a number of residents who were actively involved in the program from the start but in fact their names were not registered as target participants of the community empowerment program (CSEL, 2015b); Whereas an empowering collaboration should be community based through the invitation of citizen participation (Vangen \& Huxham, 2003).

Related to the work schedule (time line) which seems unclear, meaning that there is no agreement on working time between the manager, the companion and the target villagers; Likewise, there was no schedule for joint meetings, except for one or two socialization meetings at the beginning of the program, but according to villagers there was no scheduled time for regular joint meetings to exchange opinions or discuss issues and find solutions. Related to leadership skills (problem solving skills, facilitating, empowering, coordinating, motivating and moving), moreover giving examples that are less visible to Program Managers not clearly visible within (IM) as the Empowerment Program Manager (Vangen \& Huxham, 2003; Ife \& Tesoriore, 2014; Ufi, 2018). The role of the local community leader (Acting Head of Salas Village) is also very weak to motivate and mobilize villagers to participate in the program (MPM, 2015). Inadequate governance of program resources has also distorted the empowerment program in Salas village. In fact, 
proper resource management can play a key role in collaborative collaborative work among partners (Brinkerhoff \& Brinkerhoff, 2011).

Furthermore, common complaints that came from the collaborative partners were related to inequitable contributions and invariably partners feel that while they devote sufficient resource others lag behind often this stems from a lack of appreciation of the different kinds of resources partners from different sector, be the financial or political resources that have the greatest influence in the partnership (Sullivan \& Skelcher, 2002; Smith, 2008).

\section{Communication}

The communication factor is an important determinant factor in collaboration, including openness, frequency of formal and informal relations, and the ability to establish communication. Data from interviews showed that communication distortion by I. M., was among the most dominant factors hampering the implementation of community empowerment activities in the field. Admittedly A.I. (October 2016) thus, "... I think communication became the most problematic issue because he (IM) was in Ambon while we were here, problems are not being responded to immediately, SMS communication was replied after a few days ... We hoped he would come to see by himself and arrange the meeting with the community to help solving it, but he rarely appears in the field ..., moreover he limits communication, when problems occur, we were being asked to overcome it ourselves ... ". A. I. (October 2016). Exemplified by one of the Salas Residents (A. M., March 2017) thus, "... if there is a problem of livestock diseases (goats) there is no way out; so finally they continue to die ... "; anyway according to G. T. (March 2017), " meetings should be held once a week to get a solution"; He further said, "... the companion and the community in agriculture need to meet once a week; the facilitator must be able to direct the farmer, instead of the companion only coming to work alone, so the community is said to be lazy or does not want to be involved ..., there is a lack of communication and cooperation with us here, that's the key".

According to Field Assistant A. I. (March, 2017), "... maybe the manager also must come often but this is just the villagers seeing the assistant so they may continue to feel bored and lazy ...". The apathy and non-participation of these villagers may happened due to a lack of trust among villagers in the Program Manager, as commented by Thomson et al. (2007), that trust takes time and long interactions between partners who build trust commitments which is necessary for the implementation of collective action (villagers participation), as reflected in the narrative of a villager (AM, March 2017) namely "... we don't trust him (IM) because he rarely comes ...". A. T. as Superintendent CSEL Administration (October 2016) also said, "I always contact I. $M$. related to field problems and monthly reports but he never conveyed them to me, and he only came in 2-3 months", the same thing was also recognized by H. K. (October 2016), "I. M. tends to visit here when A. $R$. is present (on), but if A. T. is present (on) then he does not come". So, it can be concluded here that the CSR Program Manager (I.M.) tends to distort communication with stakeholders of the CSR program through the absence and avoidance of problems. 
Regarding the problem of achieving the objectives of the CSR program, it can be concluded from the acknowledgment of key informants, including those from A. T. Superintendent Admin CSEL (July, 2016) that "actually the goal of CSEL with community empowerment CSR programs is good and the budget is large for 2-3 years, but the implementation of governance in the field is not good". Manager I.M. apparently did not align the goals and concrete activities in order to achieve the empowerment goals of the CSEL CSR program. According to H. K. as the coordinator of PR CSEL (February 2017), "the program manager (I. M.) did not meet the necessary requirements, did not have the competence to manage the activity. ... ". One Salas resident even said (G. T, March 2017) that: "... actually the program did not meet the requirements, the reason was, in every household the target seed quota was enough for the life of the community for several days, the problem of the program was once negotiated but there was no solution ... "; A. I. as the facilitator acknowledged that "... indeed the goal of community economic empowerment here was not achieved, but the physical target of the program could be achieved and that was due to the fact that the field facilitators themselves were doing it themselves ... and lack of community participation ...". The lack of community participation in CSR programs could be due to: (1) lack of assessment of the needs and aspirations of citizens; (2) not prioritizing the needs of the local community; (3) existing resources are not optimal; (4) the potential of community resources is not accommodated; (5) program design and service standards are not appropriate; (6) improper use of facilities. Indeed, the problem of community interests and the utilization of resources are in fact not optimal and the success is low (Situmeang, 2016; Huxham \& Hibbert, 2008; Ufi, 2018).

In addition to the distortion factors of the Program Manager (IM), it is also recognized that there are weaknesses in the target community, for example, related to the mindset of dependency and instant mentality that is still inherent, as well as the weaknesses of CSEL including the weak supervision of CSEL, as reflected in the HK statement, CSEL PR Coordinator (February 2017), namely: "The community here has been less responsive (ignorant), considers everything to be instant, hoping from the company, ... so it can be said that the mindset of dependency still exists, making it difficult, ... because this CSR community empowerment program is expected to bring independence to themselves, it is only the Program Manager (I.M.) who is not competent to manage it ". The governance of problems of the community empowerment program experienced in the Salas village also consistently occur in the governance of the Crab Cultivation empowerment program which is also managed by I.M. (MPM) with a noncollaborative managerial behaviour (Ufi, 2018), and therefore resulted in scepticism from the community (Huxham \& Vangen, 2005; Nafi'ah, 2020). This clearly violates the basic principle for community empowerment, namely to build a strong \& effective participation process that takes into account inhibiting and conducive factors in building empowering relationships with local villagers" (Ife \& Tesoriero, 2014: 322; Ufi, 2018).

\section{E. CONCLUSION}


Based on the analysis and discussion, there are specific conclusions as follows: first, related to the issue of collective cooperation as one of the main elements of the CSEL's collaborative CSR Program for community economic empowerment to the target community of Salas Village, it can be concluded that there is a distortive tendency in the governance of the program, in term of the unilateral dominance of resources and power by the program manager (MPM) without respecting the elements of institutional collective and competent team work in accordance with the Agreement. Second, the significant distortion appears on various determinants of the collaborative CSR program, not only on stakeholder factors (domination of the manager), and on control of program resources by MPM managers (less accommodative, inadequate \& incompetent human resources, including unclear financial usage), but it also appears in the communication distortion (communication avoidance \& consensus). Based on the specific conclusions above, it can be concluded generally that the governance of collaborative CSR program between CSEL and MPM for the economic empowerment of the Salas Village community is not optimal, it is distorted by all the parties the Program Manager (misusing the contract), the community (mind set of dependency), and also the CSEL (lack of supervision \& control), therefore the CSR program fails to achieve the empowerment goals.

Accordingly, it is suggested that efforts to improve various distortive practices towards oil and gas CSR programs (CSEL) for community empowerment include: (1) the need for a good system in identifying stakeholder partners, problems \& the real needs of the community; (2) it is necessary to strengthen appropriate SOPs in the recruitment of HR in the Program Management Team with a clear and transparent position, design and scope of work, and management of program resources; (3) the need for a clear mechanism related to the involvement and participation of the community and relevant stakeholders in all stages of the program; (4) the need for SOPs related to supervision and control mechanisms, as well as a proper evaluation of the entire set of community empowerment activities that are adhered to, and carried out by partners and stakeholders in collaborative CSR empowerment programs.

\section{REFERENCES}

1. Agranoff, R., \& McGuire, M. (1998). Multi-Network Management: Collaboration and TheHollow State. Journal of Public Administration Research and Theory, 8(1), 67-91.

2. Andrews, N. (2013). Community Expectations from Ghana's New Oil Find: ConceptualizingCorporate Social Responsibility as A Grassroots-Oriented Process. Africa Today:Indiana University Press, 60(1), 55-75.

3. BP Migas, (2005). Pedoman Tata Kerja No. 017/PTK/III/2005 (SK Kepala SKK Migas No. Kpts 08/BP00000/2005-S1) Buku Kedua Tentang Pedoman Program Pengembangan Masyarakat untuk Kontraktor Kontrak Kerja di Lingkungan Kegiatan Usaha Hulu Migas. Retrieved from https//:www.hukumonline.com. 
4. Brinkerhoff, D.W. and Brinkerhoff, J.M. (2011). Public-Private Partnerships: Perspectives on Purposes, Publicness, and Good Governance. Public Administration \& Development, 31, 2-14.

5. Cheever, K. A. L. (2006). Collaborations in Public Service: Memphis Experience. International Journal of Public Administration, 29, 533-555.

6. Chrislip, D. D., \& Larson, C. E. (1994). Collaborative Leadership: How Citizens and Civic Leaders Can Make a Difference (Vol. 24). Jossey-Bass Inc Pub.

7. Citic Seram Energy Ltd (CSEL). (2015a). Profil Citic Seram Energy Limited Tahun 2015. CSEL Bulletin.

8. Citic Seram Energy Ltd (CSEL). (2015b). Laporan Program CSEL 2013-2015. CSEL Bulletin.

9. Dwiyanto, A. (2010). Manajemen Pelayanan Publik: Peduli, Inklusif, dan Kolaboratif. Yogyakarta: Gadjah Madah University Press.

10. Edi, A. C. (2014). Cross-Sector Partnership Models in CSR to Implement Poverty Reduction Initiatives in Indonesia. International Journal of Administrative Science $\mathcal{E}$ Organization, 21(2), 128-136.

11. Eweje, G. (2007). Multinational Oil Companies' CSR Initiatives in Nigeria. The Scepticism of Stakeholders in Host Community. Managerial Law, 49(5/6), 218-235.

12. Fisip Unpatti. (2017). Laporan Implementasi Program CSR DPPU Pattimura untuk Pemberdayaan Kelompok Usaha "Mama Lele" di Negeri Laha, Kota Ambon Tahun 2016-2017.

13. Frynas, J. G. (2005). The False Developmental Promise of CSR: Evidence from Multinational Oil Companies. International Affairs (Royal Institute of International Affairs 1944). Critical Perspectives on Corporate Social Responsibility, 81(3), 581-598.

14. Grudinschi, D., Kaljunen, L., Hokkanen, T. Hallikas, Sintonen, S. J. \& Puusten, A. (2013). Management Challenges in Cross-Sector Collaboration: Elderly Care Case Study. The Innovation Journal; the Public Sector Innovation Journal, 18(2), 1-22.

15. Guffey, M. K. (2006). Empowering Collaborations in the Hollow State. International Journal of Public Administration, 29, 561-575.

16. Himmelman, A. T. (1996). On the theory and practice of transformational collaboration: From Social Service to Social Justice. In C. Huxham (ed). Creating Collaborative Advantage (pp. 19-43).

17. Huxham, C., \& Hibbert, P. (2008). Hit or Myth? Stories of Collaborative Success. In J. O'Flynn, \& J. Wanna (Eds). Collaborative Governance (pp. 45-50). Australia: ANU Press.

18. Huxham, Ch. \& Vangen, S. (2005). Managing to Collaborate: the Theory and Practice of Collaborative Advantage. Abingdon, UK: Routledge.

19. Idemudia, U. \& Ite, U. E. (2006). Corporate-Community Relations in Nigeria's Oil Company: Challenge \& Imperative. Corporate Social Responsibility and Environment Management, 13, 194-206.

20. Ife, J., \& Tesoriero, F. (2014). Community Development. Alternatif Pengembangan Masyarakat di Era Globalisasi. Yogyakarta: Pustaka Pelajar. 
21. Jamal, T. B. \& Getz, D. (1995). Collaboration Theory and Community Tourism Planning. Annals of Tourism Research, 22(1), 186-204.

22. Jamali, D., Safieddine, A. M. \& Rabbath, M. (2008). Corporate Governance and CSR Synergies and Interrelationships. Journal Compilation, 16(5), 443-459.

23. Jenkins, H. \& Obara, L. (2008). Corporate Social Responsibility (CSR) in the Mining Industry - the Risk of Community Dependency. Paper presented in Center for Business Relationships, Accountability, Sustainability And Society (CRRC),1-23.

24. Kozuch, B. \& Sienkiewicz-Malyjurek, K., (2016). Factors of Efective InterOrganizational Collaboration: A Framework for Public Management. Transylvanian Review of Administrative Sciences, 47, 97-115.

25. Majelis Pemberdayaan Masyarakat (MPM). (2013). Profil MPM Tahun 2013.

26. Majelis Pemberdayaan Masyarakat (MPM). (2015). Final Report Pelaksanaan Kegiatan Pemberdayaan Pertanian dan Peternakan bagi Komunitas Desa 9 Salas Kecamatan Bula Kabupaten SBT.

27. Marek, L. I., Brock, D. J. P., \& Savla, J. (2014). Evaluating Collaboration for Effectiveness: Conceptualization and Measurement. American Journal of Evaluation, 1-19.

28. Mattessich, P. W., Murray-Close, M., \& Monsey B. R. (2001). Collaboration: What Makes It Work; Amherst H. Wilder Foundation: Saint Paul, MN.

29. Miles, M. B., Huberman, A. M., \& Saldana, J. (2014). Qualitative data analysis: A method source book. CA, US: Sage Publications.

30. Naidoo, S. (2013). A Management Dilemma: Internal Competition versus Internal Collaboration. Master Thesis. The Gordon Institute of Business Science, University of Pretoria.

31. Nafi'ah, B. A. (2020). Dynamics of Stakeholder Collaboration in Bojonegoro's Open Data Program. Policy and Governance Review, 4(1), 28-38.

32. Nasdian, F. T. (2015). Pengembangan Masyarakat. Jakarta: Yayasan Pustaka Obor Indonesia.

33. Parker, A. (2012). Key Factors and Stages of Collaboration within Community College/Automotive Industry Sector Partnerships. (Doctoral Dissertation Western Kentucky University).

34. Peloza, J. \& Falkenberg, L. (2009). The Role of Collaboration in Achieving CSR Objectives. California Management Review, 51(3), 95-113.

35. Pesmatzoglou, D., Nikolaou, I. E., Evangelinos, K. I. \& Allan, S. (2012). Extractive Multinationals and Corporate Social Responsibility: A Commitment towards Achieving the Goals of Sustainable Development or Only a Management Strategy? Review Article. Journal of International Development, 2(2), 187-206.

36. Republic of Indonesia Government Regulation No. 35 of 2004 concerning Upstream Oil and Gas Business Activities.

37. Sabaruddin, A. (2015). Manajemen Kolaborasi Dalam Pelayanan Publik: Teori, Konsep $\mathcal{E}$ Aplikasi. Yogyakarta: Graha Ilmu.

38. Scherer, A. G., \& Palazzo, G. (2010). The New Political Role of Business in a Globalized World: A Review of a New Perspective on CSR and its Implications 
for the Firm, Governance, and Democracy. Journal of Management Studies, 48(4), 899-931.

39. Seitanidi, M. M., \& Crane, A. (2009). Implementing CSR through Partnerships: Understanding the Selection, Design and Institutionalisation of NonprofitBusiness Partnerships. Journal of Business Ethics, 1-31.

40. Situmeang, I. V. O. (2016). Corporate Social Responsibility Dipandang dari Perspektif Komunikasi Organisasi. Yogyakarta: Ekuilibria.

41. Smith, C. R. (2009). Institutional Determinants of Collaboration: An Empirical Studyof County Open-Space Protection. Journal of Public Administration Research and Theory, 19(1), 1-21.

42. Smith, M., \& Beazley, M. (2002). Progressive Regimes, Partnerships and the Involvement of Local Communities: A Framework for Evaluation. Public Administration, 78, 855-78.

43. Smith, D. (2008). From Collaboration to Coercion: a Story of Governance Failure, Success and Opportunity in Australian Indigenous Affairs. In J. O'Flynn, \& J. Wanna (Eds). Collaborative Governance (pp. 76-91). Australia: ANU Press.

44. Sugiyono. (2007). Memahami Penelitian Kualitatif. Bandung: Alfabeta.

45. Sullivan, H. \& Skelcher, C. (2002). Working Across Boundaries, Collaboration in Public Service. New York: Palgrave.

46. Thomson, A. M., Perry, J. L., \& Miller, T. K. (2007). Conceptualizing and Measuring Collaboration. Journal of Public Administration Research and Theory, 19, 23-56.

47. Ufi, J. A., Rengifurwarin, Z. A., Madubun, J., Akib, H., \& Basri, M. (2020). A Collaborative Process Model In Managing Kalrez CSR Program Of Clean Water Installation To The Bula Community In East Seram Regency, Maluku-Indonesia. International Journal of Scientific and Technology Research, 9(1), 842-850.

48. Ufi, J. A. (2018). Manajemen Kolaboratif Program CSR Usaha Industri Migas di Kabupaten Seram Bagian Timur Provinsi Maluku (Studi Kasus pada Kalrez Ltd dan CSEL Ltd). (Doctoral Dissertation PPs UNM Makassar).

49. Vangen, S., \& Huxham, C. (2003). Nurturing Collaborative Relations: Building Trust in Inter-organizational Collaboration. The Journal of Applied Behavioural Science, 39(1), 5-31.

50. Yandra, A., Utami, B. C., \& Husna, K. (2020). Distortion of Government Policy Orientationin Public-Private Partnership (PPP). Policy and Governance Review, $4(1), 40-54$. 